\title{
Imbibition and germination in the seeds of Glinus lotoides $\mathbf{L}$.
}

\author{
RAMESH C. BHATIA
}

Department of Botany, Government Science College, Gwalior 474009, India

\begin{abstract}
Imbibition in the seeds of Glinus lotoides $\mathrm{L}$. varied under different temperatures. The optimum temperatures for imbibition and germination were different. Fifty-five percent imbibition was essential for germination and this capability was achieved by 12 weeks old seeds. With growing duration of dry storage, imbibition and germination increased, although germination declined on prolonged dry storage for over 36 weeks. A soil moisture of $50 \%$ was essential and $100 \%$ was optimal for germination. A correlation was found between imbibition and germination.
\end{abstract}

\section{INTRODUCTION}

Glinus lotoides L. is an exclusive annual weed of drying temporary pond beds in the tropical and sub-tropical regions of the world. It grows luxuriantly in the extreme hot and dry conditions of summer when the other herbaceous vegetation of nearby upland areas dries up completely.

Its wide but specialized distribution has attracted the author's attention and prompted imbibition and germination studies of its seeds. Imbibition is actually a process of water uptake and the penetration of water through the seed coat; hydration of the interior of the seed is essentially an absorption process, involving the entire seed and preparing it for germination.

\section{MATERIAL AND METHODS}

Ripe Glinus lotoides L. fruits from five different localities of Gwalior were collected on 6.6.81. They were mixed together, dried under bright sunlight and stored in corked glass bottles in a warehouse, the thermal conditions of which ranged from $25-37^{\circ} \mathrm{C}$. The seeds were healthy and free from any disease. They were taken out from their fruits whenever required. The viability of the seeds was $96 \%$, as tested by 
T.T.C. (2, 3, 5 triphenyl tetrazolium chloride) treatment (Roberts, 1972). The temperatures applied to study imbibition and germination were: $\mathrm{T}_{1}$ - laboratory temperature which ranged from $18-29.8^{\circ} \mathrm{C} ; \mathrm{T}_{2}-$ a constant temperature of $35 \pm 1.8^{\circ} \mathrm{C} ; \mathrm{T}_{3}$ - a constant temperature of $10 \pm 1.9^{\circ} \mathrm{C} ; \mathrm{T}_{4}$ - alternating temperature of $35 \pm 1.8^{\circ} \mathrm{C}$ and $10 \pm 1.9^{\circ} \mathrm{C}$ each for half the duration of imbibition and $12 \mathrm{~h}$ each during a day for the seeds immersed for $24 \mathrm{~h}$ and more. In all the experiments 3 replicates were made.

The imbibition was determined in terms of percent absorption of water it was expressed as the difference in the weight of seeds after and before immersion in distilled water for different time periods at various temperatures. The water content in the seed before imbibition was not measured and the results of imbibition are based on the difference in the water content in the seed after and before imbibition. Each time, 100 seeds were taken in each Petri dish in 3 replicates to determine the mean imbibition percent of the seed. Germination was studied in sterilised Petri dishes on moist filter paper. The emergence of the radicle was taken as the criterion for germination. Observation was carried out for 90 days in each case until complete germination was obtained. The different soil moisture levels i.e. 10, 20, 40, 60, 80 and 100\% were maintained on the basis of oven dry weight of the pond bottom soil. The data were statistically analysed as suggested by $\mathrm{Snedecor}$ and $\mathrm{Cochran}$ (1968).

\section{RESULTS AND DISCUSSION}

\section{A. Effect of temperature and duration of immersion on imbibition}

The imbibition percentage at different temperatures and after various periods of time was determined in 24 weeks old seeds (Table 1).

The percentage of water imbibed during a period varied under different temperatures. The laboratory temperature which ranged from $18-29.8^{\circ} \mathrm{C}\left(\mathrm{T}_{1}\right)$ was most favourable while the constant high temperature of $35^{\circ} \mathrm{C}\left(\mathrm{T}_{2}\right)$ and low temperature of $10^{\circ} \mathrm{C}\left(\mathrm{T}_{3}\right)$ were harmful for imbibition. However, alternate temperature of $35^{\circ} \mathrm{C}$ and $10^{\circ} \mathrm{C}$, each for $12 \mathrm{~h}$ period per day $\left(\mathrm{T}_{4}\right)$ was sufficiently favourable for imbibition. The immersion of seeds for $72 \mathrm{~h}$ was the optimum duration for imbibition. The cbserved variance ratio $(F)$ revealed that both temperature and duration of immersion significantly affected imbibition. The least significant difference (L.S.D.) or critical difference (C.D.) at 5\% probability also indicated that the percentage of water imbibed significantly varied due to temperature $( \pm 5.71)$ and duration of immersion $( \pm 6.39)$, although the temperature was of greater importance. Shull (1.920), M a yer and M a y ber 
Ta ble 1

Effect of temperature and duration of immersion on imbibition

\begin{tabular}{cccccc}
\hline Tempera- & \multicolumn{5}{c}{ Imbibition $\%$ in seeds immersed for hours } \\
\cline { 2 - 6 } ture & 0.5 & 4 & 12 & 24 & 72 \\
\hline $\mathrm{T}_{1}$ & 101.13 & 112.5 & 112.8 & 113 & 174.8 \\
$\mathrm{~T}_{2}$ & 69.93 & 72.5 & 77.2. & 77.92 & 78.57 \\
$\mathrm{~T}_{3}$ & 4.3 & 11.2 & 61.5 & 71.7 & 81.79 \\
$\mathrm{~T}_{4}$ & 71.2 & 75.1 & 83.7 & 94.5 & 158.3 \\
\hline
\end{tabular}

Analysis of variance

\begin{tabular}{ccccc}
\hline & \multicolumn{4}{c}{ Source of variation } \\
\cline { 2 - 5 } Values & replication & $\begin{array}{c}\text { temperature } \\
(\mathrm{T})\end{array}$ & $\begin{array}{c}\text { duration } \\
\text { of immersion } \\
(\mathrm{D})\end{array}$ & $\mathrm{T} \times \mathrm{D}$ \\
\hline $\mathrm{F}$ & $0.28^{\mathrm{NS}}$ & $100.08^{*}$ & $33.65^{*}$ & $10.37^{*}$ \\
\hline LSD & 4.95 & 5.71 & 6.39 & 12.78 \\
\hline
\end{tabular}

NS - nonsignificant at $0.05 \mathrm{P}$; * - significant at $0.05 \mathrm{P}$; LSD - least significant difference at $0.05 \mathrm{P}$;

$\mathrm{F}$ - variance ratio observed.

(1963) and Kozlowski (1972) reviewed the factors affecting imbibition of water by seeds.

B. Effect of temperature on germination

The seeds dry stored for 24 weeks were kept for germination under different temperatures $\left(\mathrm{T}_{1}-\mathrm{T}_{4}\right)$. The seeds did not germinate under $\mathrm{T}_{1}$ and $\mathrm{T}_{2}$ while $6 \%$ and $48 \%$ germination was observed under $\mathrm{T}_{3}$ and $\mathrm{T}_{4}$, respectively. This showed that the optimum temperature for germination was $\mathrm{T}_{4}$. It was noted that the optimum temperature for imbibition and germination were different. Similar observations were made by $\mathrm{B} h$ a ti a (1983) in Heliotropium supinum L.

\section{Effect of dry storage on imbibition and germination}

The seeds dry-stored for periods of different duration were immersed in distilled water for $72 \mathrm{~h}$ at $\mathrm{T}_{4}$ to determine their imbibition percentage of water. The germination percentage of the seeds of different ages was also known at $\mathrm{T}_{4}$ (Table 2).

The imbibition and germination percentage increased with the age of the seeds. During aging the seeds were dry-stored in a warehouse. Dry storage caused after-ripening in the seeds which most probably increased the permeability of the seed coat to water. After-ripening of the seeds for 12 weeks during dry storage was essential for germination 
Table 2

Effect of dry storage on imbibition and germination

\begin{tabular}{ccrrrrrr}
\hline \multirow{2}{*}{\begin{tabular}{c} 
Parametr \\
\cline { 2 - 9 }
\end{tabular}} & \multicolumn{6}{c}{ Duration of dry storage in weeks } \\
\hline Imbibition & 18.8 & 36.3 & 54.7 & 1111.5 & 193.2 & 210.8 & 223.4 \\
\hline Germination & 0 & 0 & 29 & 48 & 78 & 92 & 88 \\
\hline
\end{tabular}

Analysis of variance

\begin{tabular}{ccccc}
\hline & \multicolumn{4}{c}{ Source of variation } \\
\cline { 2 - 5 } Values & \multicolumn{2}{c}{ imbibition } & $\begin{array}{c}\text { duration } \\
\text { of dry } \\
\text { storage }\end{array}$ & germination \\
\hline replication & $165.42^{*}$ & $4.79^{*}$ & $\begin{array}{c}\text { duration } \\
\text { of dry } \\
\text { storage }\end{array}$ \\
\hline LSD & $9.69^{\mathrm{NS}}$ & 14.82 & 3.95 & $205.03^{*}$ \\
\hline
\end{tabular}

Explanation as in Table 1.

and the imbibition percentage in such seeds was approx. 55\%. This revealed the fact that $55 \%$ imbibition was essential for germination and this capability was achieved in seeds upon their dry storage for 12 weeks. The seea's which had maximum germination of $92 \%$ imbibed $211 \%$ water. The duration of dry storage significantly affected both imbibition and germination. Correlation analysis between imbibition and germination of the seeds after varied periods of dry storage was carried out. The correlation coefficient " $r$ " was 0.97 indicating that a strictly functional relationships did not exist between them, although there was a trend. The value of " $r$ " was a positive fraction, hence increased imbibition tended to be associated with increased germination. By the $t$ test (test of significance) it was found that the correlation coefficient was significant at 5 and $1 \%$ levels of probability when the total number of observations in each case was $21(\mathrm{n}=21)$. Mullick and $\mathrm{Chatterji} \mathrm{(1967)} \mathrm{con-}$ cluded that a prolonged period of dry storage of the seeds of Clitoria ternatea $\mathrm{L}$. increased imbibition and germination and the physical and chemical treatments which were proved advantageous to imbibition were also benefical to germination. Mo h n ot and $\mathrm{Ch}$ at te $\mathrm{rji}$ (1965), $\mathrm{C} \mathrm{ha-}$ tter ji and Mohnot $(1967 ; 1968)$ and Bhatia (1983) made similar observations.

D. Soil moisture requirement for germination

40 weeks old seeds were placed for germination at different soil moisture levels under $\mathrm{T}_{4}$ (Table 3 ).

For initiation of germination, a soil moisture level of $50 \%$ was 
Table 3

Soil moisture requirement for germination

\begin{tabular}{cccccccc}
\hline \multirow{2}{*}{$\begin{array}{c}\text { Parametr } \\
\%\end{array}$} & 10 & 20 & 40 & 50 & 60 & 80 & 100 \\
\cline { 2 - 8 } Germination & 0 & 0 & 0 & 5 & 19.3 & 56.7 & 70 \\
\hline
\end{tabular}

Analysis of variance

\begin{tabular}{ccc}
\hline \multirow{2}{*}{ Values } & \multicolumn{2}{c}{ Source of variation } \\
\cline { 2 - 3 } & replication & soil moisture \\
\hline F & $\mathbf{0 . 1 3 ^ { \mathrm { NS } }}$ & $190.31^{*}$ \\
\hline LSD & 3.06 & 4.68 \\
\hline
\end{tabular}

Explanation as in Table 1.

essential and for maximum germination, $100 \%$ soil moisture level was required. B h a ti a $(1966 ; 1983)$ observed that the optimum soil moisture levels for germination in the seeds of Trigonella occulta Delile and Heliotropium supinurn L. were $60 \%$ and $44 \%$, respectively. Both these species are close associates of Glinus lotoides $L$. This indicates that the soil moisture requirements for initiation and maximum germination vary in the different species of the same community. In nature also, the seedlings appear on the drying pond bed when sufficient moisture still remains there. This shows a definite correlation between environmental requirements for germination and ecological conditions occurring in the habitat of the plant and the seeds.

\section{REFERENCES}

Bhatia R. C., 1966. Autecological study of some weed Flora at Gwalior and suburbs. Ph.D. Thesis, Vikram University, Ujjain, India.

Bhatia R. C., 1983. Imbibition and germination in the seeds of Heliotropium supinum L. Acta Soc. Bot. Pol. 52: 45-51.

Chatterij U. N., Mohnot K., 1967. Thermo-physiological investigations on imbibition and germination of seeds of certain arid zone plants. I - The seeds of Mimosa hamata Willd. Acta Agron. Acad. Sci. Hung. 16: 7-16.

Chatterji U. N., Mohnot K., 1968. Eco-physiological investigations on the imbibition and germination of seeds of Prosopis juliflora L. Proc. Symp. Recent Adv. Trop. Ecol, 1: 261-268.

Kozlowski T. T., 1972. Seed Biology. Vol. II. Academic Press, London.

Mayer A. M., Ma yber A. P., 1963. The germination of seeds. The Macmillan and Co., New York p. 40.

Mohnot K., Chatterji U. N., 1965. Chemico-physiological studies on the imbibition and germination of seeds of Parkinsonia aculeata L. Osterr. Bot. Zeit. 112: $576-585$. 
M ullick P., Chatterji U. N., 1967. Eco-physiological studies on seed germination. Trop. Ecol. 8: 117-125.

R o berts E. H., 1972. Viability of seeds. Chapman and Hall, London.

$\mathrm{Shu} 11 \mathrm{C}$. A., 1920. Temperature and rate of moisture intake in seeds. Bot. Gaz. 69: 361-390.

Snedecor G. W., Cochran W. G., 1968. Statistical methods. Oxford and I.B.H. Publishing Co., New Delhi.

\section{Absorpcja i kiełkowanie nasion Glinus lotoides}

\section{Streszczenie}

Absorpcja nasion Glinus lotoides L. zmienia się $\mathrm{w}$ zależności od temperatury. Optymalne temperatury dla absorpcji i kiełkowania są różne. Do kielkowania jest niezbędna 55\% absorpcja i ta zdolność jest osiągana przez nasiona przechowywane przez 12 tygodni. W czasie suchego przechowywania nasion absorpcja i kielkowanie zwiększają się, chociaż kielkowanie obniża się u nasion przechowywanych dłużej niż 36 tygodni. 50\% wilgotność gleby jest niezbędna, a 100\% wilgotność jest optymalna dla kiełkowania. Istniejø korelacja między absorpcją a kiełkowaniem. 